\title{
11. Migrants, Labourers and Landowners at the Lihir Gold Mine, Papua New Guinea
}

NCHOLAS A. BANTON

\section{Introduction}

The Papua New Guinea (PNG) landscape is punctuated by large-scale resource extraction projects that have created concentrated nodes of hyper-intensive capital development that draw people from near and far. Existing patterns and processes of uneven development have found new expression in these enclave spaces that have reshaped the national 'metageography' of development (Sidaway 2007). These new centres attract hopeful migrants who seek economic opportunities and access to services that remain absent throughout many rural districts in contemporary PNG. The movement of people around resource development projects, or what the International Finance Corporation calls 'project-induced in-migration' (IFC 2009), or what Glenn Banks has more aptly described in the PNG context as 'rural-to-resource migration' (Banks 2005: 135), is a common social phenomenon in developing country contexts. While the drift towards resource development projects throughout PNG is motivated by similar aspirations as rural-to-urban migration (Strathern 1975; Clunies Ross 1984), and bears some resemblance to rural-to-rural migration, there are several distinguishing spatial and temporal features. 
Migration has been a central feature of PNG's human landscape for centuries, as part of the maintenance of kin relations, marriage, trade and exchange or displacement from warfare and, more recently, in response to environmental hazards (Connell 2012). In many cases, it is regulated by customary norms and reciprocal obligations over extended periods of time. In contrast, rural-to-resource migration typically occurs at a greater pace over a more compressed period of time. There is often an increased level of in-migration during project construction, but it can vary over time as operations expand and contract. It is strongly influenced by existing regional development and settlement patterns that are usually concentrated around project areas. While most migrants draw upon regional networks and existing social relations with project area communities, the process is also formulated as an opportunistic strategy whereby migrants with previously limited social connections to the project area forge new relationships in order to legitimise their presence. For many migrants, the intention is to stay as long as the resource project remains in operation, or as long as it remains socially and economically feasible. In addition to unprecedented forms of social and environmental change generated by large-scale resource development (Bainton 2010; Golub 2014; Kirsch 2014), in-migration places enormous pressure upon host communities, project operators, and local government authorities. If it is readily acknowledged that resource projects provide many of the pull factors that influence regional migration patterns, it is also evident that host communities play a major determining role in shaping in-migration and settlement patterns. As such, in-migration can create complex and overwhelming consequences, and the question of so-called 'migrant management' is a vexed issue for all parties.

This chapter presents material collected through a long-term demographic monitoring program that covers the Lihir Islands in PNG's New Ireland Province, where the Lihir gold mine is situated. The scale of in-migration around the Lihir project is smaller than that associated with some resource projects on the PNG mainland, but an awareness of this difference has only served to sharpen local concerns over the growing presence of outsiders in Lihir. Elsewhere I have explored Lihirian cultural and political responses to migrants, which are largely characterised by the emergence of a strong sense of ethnic and cultural difference that Lihirians regularly articulate in relation to outsiders, the transformation of guests into strangers, and the codification of Lihirian identity (Bainton 2009). In different ways, each response attempts to manage or exclude 
outsiders in order to contain mine-related benefits within Lihir, and these responses can be seen as part of the social relations of compensation (see Chapter 1, this volume). In this chapter, I look more closely at the migrant population. I propose that in-migration, or rural-to-resource migration, is best understood as a socially embedded phenomenon that arises from the strategic opportunism exercised by both migrants and host communities or, in other words, as the socioeconomic result of a dialectical resourcefulness. In Lihir, this is best exemplified through the complex and often contradictory intersection between migrant labour and landowner business development, the strategies that migrants pursue in order to secure access to land, accommodation and livelihoods, and the precarious nature of their lives. I conclude with some reflections on the practical implications for the management of this phenomenon.

\section{Resource Enclaves, Project Corridors and Migrant Groups}

The legal recognition of customary landownership in PNG ensures that resource companies are drawn into intense and continuing engagement with local landowners or their representatives over access to land and resources and the operational activities that occur once leases have been granted. Benefit-sharing agreements outline the conditions for the payment of statutory compensation and royalties to lease-area landowners and the provision of a broader set of benefits such as employment opportunities, service delivery and economic opportunities, which may also filter out to the wider host community (Filer 2012). Even when resource development projects require the relocation of village communities, landowners often remain within close vicinity of the project. Notwithstanding trips abroad or the minority elite who establish themselves in urban centres like Port Moresby, it is rare for local landowners to permanently migrate away from project areas and their related disturbances. ${ }^{1}$ If this reflects the difficulties that people may face in securing access to land in other areas, it also reflects their desire to maintain claims over new forms of development and the fear that, by relocating elsewhere, they might relinquish any rights

1 The PNG context tells a rather different story compared to other mining-dependent countries like Peru, where local communities are known to migrate away from the project area, while more skilled migrants settle around the mine (Bury 2007). Thanks to Glenn Banks for bringing this point to my attention. 
over this new 'inheritance'. In some locations, such as Porgera, it also reflects a fear among landowners that other people may come and take up residence on their land if they do not stay to protect their interests. Social pressures increase as people from neighbouring villages, and from other valleys, islands and provinces similarly gravitate towards these areas in search of the 'good life'. As a result, the nature and scale of rural-toresource migration often irreversibly restructures regional networks and relationships. Local communities may well feel dispossessed, marginalised or displaced, not only by the project, but from the sheer number of people arriving on their lands (Banks 2009: 49).

Without overstating the differences, it is possible to draw some basic distinctions between migrant 'types' around resource development projects in PNG. The bulk of the migrant population is often composed of semi-skilled rural people seeking employment with local companies or the developer, or indirect engagement with the resource economy as entrepreneurs or market sellers, or access to better services. And in some locations the glitter of artisanal gold mining is simply too much to resist. These migrants differ from the small number of people posted to project areas to work in essential government services where accommodation is provided, and skilled professionals and tradespeople who come to manage or work for local businesses. These migrants are distinct from the employees of the developer or major contractor companies, who are often engaged on fly-in/fly-out arrangements from their home and stay in camp accommodation during their work rotation. ${ }^{2}$

The Wau-Bulolo region of what is now Morobe Province hosted the first major mining operations in PNG in the 1920s and drew in large numbers of migrants, many of whom were recruited from the Sepik region through the government's labour recruitment program. Pre-existing tensions surrounding the presence of outsiders working on plantations and in administrative roles in Bougainville during the period after World War II were compounded when mining operations started in that region in the early 1970s. The presence of thousands of outside labourers, termed 'redskins' by local Bougainvilleans due to their comparatively light skin colour, was a major contributing factor that led to widespread dissatisfaction around the operation of the mine (Nash and Ogan 1990; also Chapter 12, this volume). By contrast, the Misima gold mine in

2 For an overview of fly-in/fly-out employment in the PNG mining sector, see McGavin et al. (2001). See also Storey (2001) and Markey (2010). 
Milne Bay Province is one of the few operations in PNG that was not impacted by in-migration, partly as a result of its remote location and the lack of transport options, the limited economic opportunities for contractors, and the policy adopted by Misima Mines Ltd to maximise local recruitment.

At the Ok Tedi mine daily life for the previously isolated Wopkaimin people has certainly been affected as thousands of people from cognate Mountain Ok language groups and from further afield have moved into the area and settled around Tabubil town. The prospect of instant riches sparked a gold rush at Mt Kare and lured vast numbers to that inhospitable landscape (Ryan 1991; Vail 1995). But nothing compares to the Porgera gold mine, where tens of thousands of people have been drawn to the Porgera Valley by the allure of mine-related development and an artisanal gold mining boom (Callister 2008). The pre-mining population has increased from roughly 2,500 people recorded in 1957 (Meggitt 1957: 33), to approximately 10,000 in 1990 (Filer 1999: 3) and an estimated 45,000 in 2012 (BGC 2012). ${ }^{3}$ Many people have exploited a combination of customary ties and local Ipili people's notions of incorporation that make it possible for people from outside the valley to come and live there (Golub 2007). In-migration was further encouraged as Ipili people strategically allowed 'outsiders' to come and reside in the valley in order to increase the number of their allies and supporters for greater security and to expand the network of economic possibilities that they might exploit. The socially embedded nature of in-migration makes it difficult for local community members to now 'manage' or stop the influx of outsiders. Ipili people fear retribution for any attempt to remove outsiders, particularly from their neighbours who feel entitled to benefit from the mining project. Mounting pressure to resettle the large population residing in congested settlements on lease areas close to mining activities presents an intractable problem for all parties: the complex ties between landowners and migrants have made it impossible for the Porgera Joint Venture to forge a clear distinction between these household units and to establish eligibility for relocation packages (Kemp and Owen 2015). At the same time, as the company and local authorities contemplate the eventual closure of the mine, they face difficult questions around the provision of post-mining services that will adequately support a large community that is heavily concentrated around the project area with

3 In the absence of firm census figures, estimates of the population resident in the Porgera Valley have been the subject of some debate. A recent report for the Restoring Justice Initiative suggests that the population in the valley may be as high as 73,000 people (Robinson 2014). 
little incentive to move elsewhere. The question of relinquishing the mining lease at the end of its term may become seriously problematic in light of the difficulties surrounding the safe decommissioning of the mine site when hundreds of so-called 'illegal miners' (BGC 2010) continue to enter the lease area and tunnel and sift through stockpiles and pit walls in search of gold. These miners will doubtless expect to have access to remaining gold traces as their main form of livelihood in the post-mining era.

Whereas mining operations often produce more concentrated impact zones, and benefit streams tend to accumulate in quite discrete geographic locations, oil and gas projects are temporally different and generate more spatially distributed impacts. ${ }^{4}$ PNG's new liquefied natural gas project, operated by ExxonMobil, sources gas from various fields and wells, incorporating these locations into a wider productive landscape as gas is piped to export facilities on the outskirts of Port Moresby. This gas network covers the lands of many culturally and linguistically different groups and will reconfigure relationships at a much larger scale as a more diverse group of people gravitate towards wells and proposed pipeline corridors in anticipation of economic opportunities (Goldman 2009). Instead of coalescing around a single project site, the extended network of facilities has provided migrants with a multitude of possible destinations, and this could mean that a much greater number of communities will experience social and demographic pressures without the development offsets that are sometimes found in mining enclaves.

\section{Lihir and Its Gold Mine}

The Lihir Islands are situated off the east coast of mainland New Ireland and are divided into 15 local-level government wards. The Lihir gold mine, which commenced operations in 1997 and is currently operated by Newcrest Mining Ltd, is located in Ward 2 on the main island of Aniolam (Figure 11.1). While the mining lease areas occupy slightly more than 12 per cent of Aniolam Island, the social and economic

4 Of course, some projects, like the Ok Tedi mine, have generated far-reaching downstream impacts. In other locations, mining projects may develop infrastructure across wide geographic zones, including ports, pipelines, power stations, roads and railways that increase both the possibilities and complexity of in-migration patterns. Work elsewhere, particularly in Africa and South America, where oil and gas pipelines thread across parts of those continents, provides useful points of comparison (e.g. Thibault and Blaney 2003; Lavachery et al. 2005; Smith 2005; Finer et al. 2008). 
footprint of the operation has encompassed the entire island group and all villages have experienced substantial social, economic, cultural and political change. 5 As with other resource development projects in PNG, unmanaged in-migration has generated major social impacts and numerous operational risks.

Lihirians historically lived in scattered hamlets along the coastal strips. Land and other property rights are generally held by matrilineal descent groups, although this pattern is changing due to greater emphasis being placed on the nuclear family unit and fathers looking to secure land and resources for their children or pass on permanent houses to their sons. Matrilineages traditionally occupied their own hamlets, and male leaders were responsible for maintaining the men's house of the lineage. Men's house sites were a primary locus for the social reproduction of lineage groups through the performance of customary feasts and the exchange of pigs and shell money. Mining has introduced greater amounts of cash and commodities that are now incorporated into these events, thereby boosting the local ceremonial economy and reaffirming the symbolic importance of the men's house (Bainton and Macintyre 2016).

Lihirians have strong cultural links throughout New Ireland with people from the Namatanai, Tanga and Tabar districts, and with people from West New Britain. Historical migration patterns, both within Lihir and the broader region, tended to be more short term. People travelled to other areas to engage in feasting and exchange activities and to maintain relations established through marriage and clan ties. Reciprocal notions of hospitality, coupled with comparatively less pressure upon land, meant that if people chose to stay on for extended periods of time they could be granted access to land and resources for subsistence. Some people also migrated to pursue work on plantations or in urban areas.

5 The total land mass on Aniolam Island is 19,960 hectares. The combined area of the special mining lease, the lease for mining purposes, and the mining easement is 2,527 hectares-about 12 per cent of the island. 


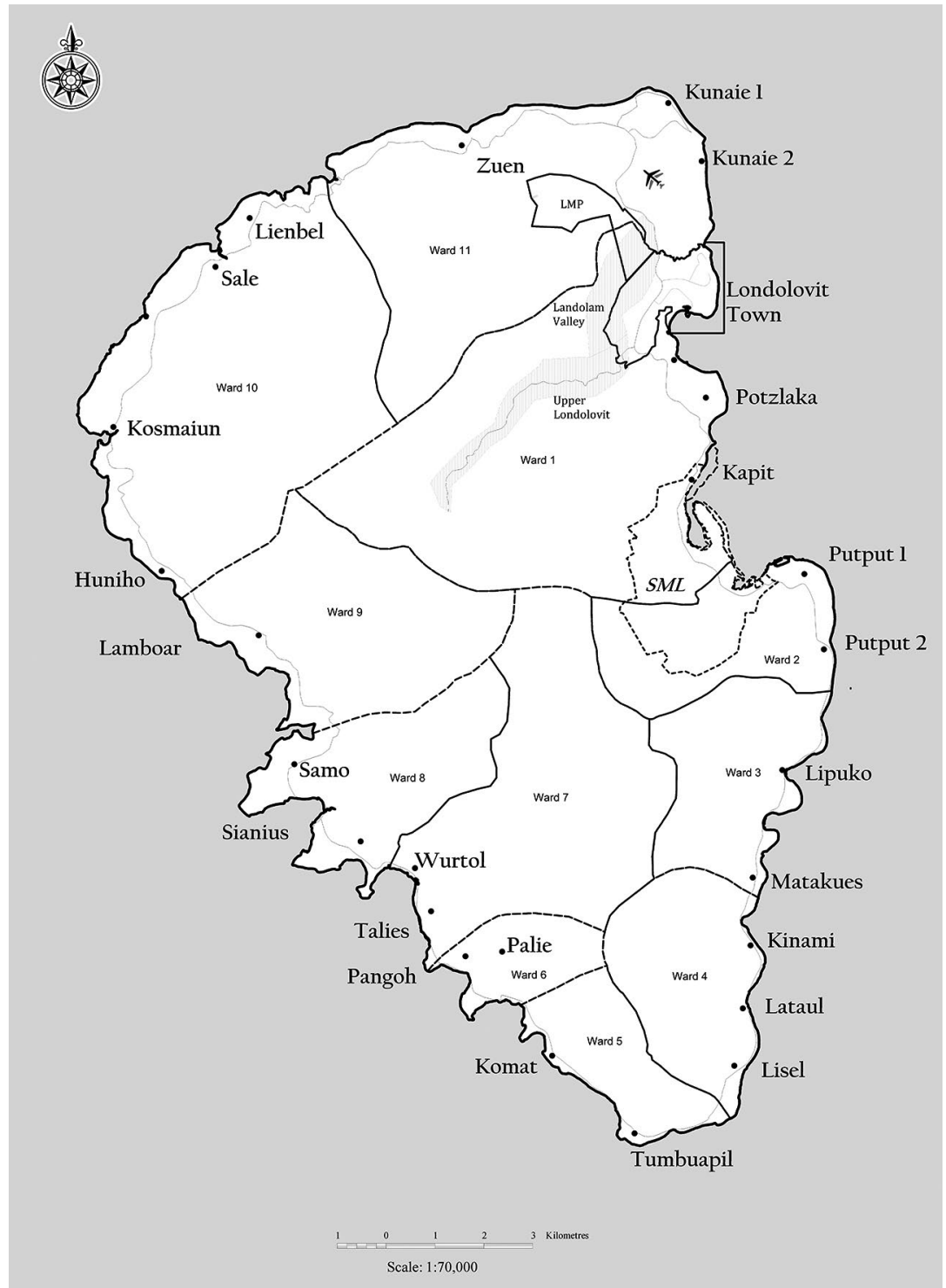

Figure 11.1 Villages and council wards on Aniolam Island.

Source: Newcrest Lihir Lands and Geographic Information System unit. 
At the crudest level, resource development has divided Lihir into 'affected' and 'non-affected' areas. This distinction is crystallised in the 1995 'integrated benefits package' (IBP) agreement and is based upon whether village land has been disturbed for mining purposes. ${ }^{6}$ Those Lihirians who own land within the mining lease areas receive royalties, compensation and other economic benefits. The wider community benefits in more indirect ways such as employment, service provision and community development projects. Development of the mine in the Louise Caldera required the relocation of two coastal villages, Putput and Kapit (Owen and Kemp 2014). The physical relocation of Kapit village and the subsequent resettlement programs have been complex and protracted, and are still incomplete. Due to a lack of customary land within the vicinity of the original village of Kapit, the community was divided as households were relocated around Lihir to areas where they have clan connections. Few of these relocated families have strong land tenure rights in these new locations, further compounding their vulnerability. The people of Putput were resettled as a relatively cohesive community to nearby land where they had customary land rights. Putput village is largely composed of Lihirians who claim ownership over land within the 'special mining lease' (SML) area and is consequently positioned at the top of the new socioeconomic hierarchy. Other nearby villages, including Zuen, Kunaie and Londolovit, also contain many Lihirians who claim ownership over land within the SML and the 'lease for mining purposes' (LMP) area. These villages were not relocated to make way for the mining operation, but because portions of their land were alienated for the LMP, the airport or the mining easements, these villages are also classified as affected areas and have received specific benefits and compensation.

Most Lihirians maintain high expectations for mine-derived development, and many lease-area landowners feel entitled to an exclusive claim over economic benefits and opportunities that arise from the project. At

6 The 1995 IBP was signed by the developer, the landowners and the government. It was organised into four chapters which represented the fourfold classification of compensation presented by the landowners during negotiations-compensation for destruction, development, security and rehabilitation. It contains the compensation and relocation agreements and three memoranda of agreement (MOAs) between the landowners and the three tiers of government, as well as the environmental monitoring plan and provisions for trust funds. The MOAs establish the distribution of royalties and define the responsibilities and undertakings of the parties in relation to the development of the mine and its benefits for the community. The MOAs were included in the agreement so that the landowners could see the entire package of compensation and benefits they would receive from the mining operation. The IBP agreement was revised in 2007 (Bainton 2010) and is the subject of a current review process. 
the same time, the technical or legal distinction between affected and non-affected areas fails to capture the extent to which the so-called nonaffected villages have also experienced the social impacts arising from the operation. Consequently, the unequal distribution of the costs and benefits associated with the project has generated considerable tensions and divisions throughout Lihir.

\section{Demographic Monitoring}

The social impact monitoring program for the Lihir gold mine, managed by the company's social performance department, has maintained a consistent focus on demographic monitoring. The current program has its origins in the baseline population survey and landowner identification work, and the earlier mapping of Lihirian men's houses (Filer 1992; Burton 1994). In 1994, John Burton developed the Lihir 'village population system' (VPS) database built on his customised genealogy software. An in-house team of research officers continues to work closely with a group of village-based informants to collect quarterly population updates for the VPS database, and since 2003 demographer John Vail has provided the team with technical support and produced annual population reports. The VPS now comprises a genealogical database of the Lihirian population and a database for the non-Lihirian population. The reason for this separation reflects Lihirian concerns over maintaining the 'purity' of Lihirian data to ensure that non-Lihirians are not mistakenly ascribed Lihirian status, which might allow them to access mining benefits. These two databases are linked through a third geographic information system database that combines aerial imagery and ground-level surveys, and contains information on the location of residential houses and their inhabitants.

Research officers and village informants have maintained relatively accurate data on the Lihirian population, partly due to the quality of the original genealogical survey, the ease of identifying Lihirians, and because many Lihirians tend to reside close to their natal village. On the other hand, it has proven more difficult to maintain accurate data on the migrant population because it is more mobile and less integrated into Lihirian society. For this reason, a residential household mapping 
approach has been required. Demographic datasets collected through a variety of other sources, including birth and death records from the health centres, attendance at maternal and child health clinics, school enrolment records and employment applications, are cross-referenced for inclusion in the VPS.

Overall, the longevity of this program has started to allow for a more sophisticated analysis of changes in fertility, mortality and life expectancy in the Lihirian population, and a more detailed understanding of the migrant population and its residential patterns. The VPS has proven to be an important corporate risk management tool, as it allows for a detailed level of information on local demographic trends and broader stakeholder connections. It also provides the basis for understanding the customary ownership of mining lease areas, the lack of which has been the source of considerable social tension and financial cost at other operations in PNG. In the absence of reliable government census data, the VPS has been of great value to local stakeholders, including the landowner association and the local-level government, and it has assisted with community development planning and land dispute resolution. While the VPS has many positive applications, and is maintained with the express endorsement of the landowner association and the local-level government, in its capacity as the curator or manager of this genealogical and personal identity database, the company has a clear duty of care to safeguard against its improper use and ensure its preservation for future generations (Burton 2007).

\section{Demographic Shifts in the Mining Era}

Over the past century the Lihirian population has increased from around 3,600 in the 1920 s to 5,500 in 1980, and approximately 9,890 in $1995 .^{7}$ By the end of 2013 the Lihirian population was 16,095 (Figure 11.2). These shifts partly reflect a combination of improved community health

$7 \quad$ It was estimated that in the early 1980s around 500 Lihirians were absent from the islands. Many of these Lihirians were married to non-Lihirians and later returned to Lihir with their families to seek better living conditions. By the late 1990s, this group of returnees comprised some 2,000 people. Many of the women in this group were of childbearing age, which contributed to natural population increase. 
facilities, increased life expectancy and lower infant mortality rates. ${ }^{8}$ The bulk of the Lihirian and migrant population now resides in a broad arc across the northeast of Aniolam Island, which is mainly a result of people moving closer to services and employment opportunities.

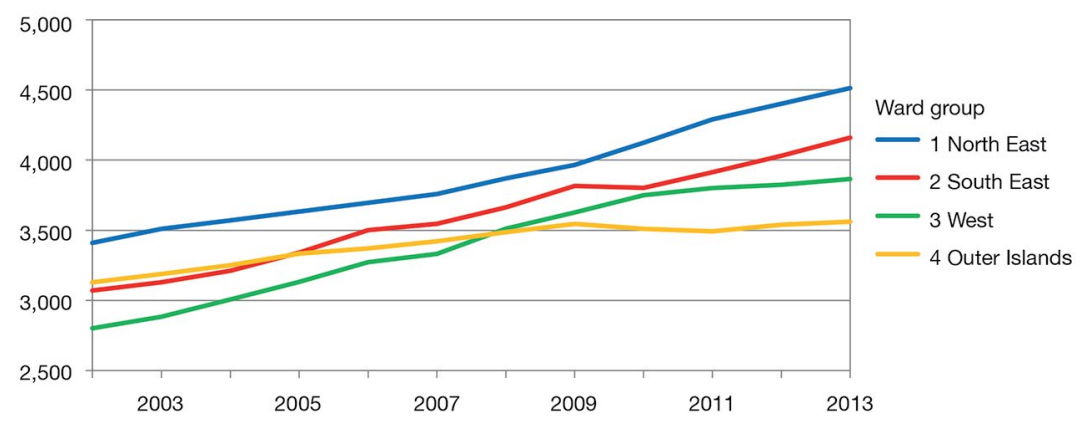

Figure 11.2 Lihir population by ward group, 2002-13.

Source: Newcrest Lihir Social Impact Monitoring unit.

The expanding migrant population in Lihir can be broadly divided into three categories: those who claim some form of existing or historical social connection; those who have forged relatively recent relations with Lihirians; and those people with very tenuous social connections in Lihir.' In local Tok Pisin terms, Lihirians tend to regard people from the first two groups as ol wantok (literally 'one talk'), a flexible and contextually contingent relational category that can be extended to relatives, people who share the same language or ancestry, people from the same province or region,

8 In 1997, John Burton concluded that single motherhood had been a common feature in Lihir since Independence, a period for which accurate data was available (Burton 1997a). Datasets for 1975-97 indicated that one in every seven families was headed by a woman, and one in every nine births, or about 10.8 per cent of all births, was to a single mother. Inquiries as to the whereabouts of the father were met with the habitual reply em karim pikinini long rot ('the child was conceived during her wanderings'). More recent data suggests a further increase, with 36 per cent of births recorded to single mothers in 2014. We might conclude that this increase is a result of rapid social changes; however, more research is required to understand whether these mothers are indeed single, or if this reflects an increase in de facto relationships that Lihirians may not report or 'recognise' as legitimate marriages for religious or cultural reasons. At this stage, it is impossible to conclude whether an increase in the number of single mothers has contributed to population growth. Similarly, more work is required to understand whether the growth rate has actually slowed over the past decade as more women have become empowered through access to employment and incomes.

9 This does not include temporary visitors from the surrounding parts of New Ireland Province, who mainly come for specific purposes for short periods of time and later return to their home village or town, or the fly-in/fly-out workforce associated with the mining operation. 
or simply friends. ${ }^{10}$ In other instances, Lihirians regard incorporated migrants as their bisnis ('business'), a term that Lihirians use to denote both their extended relatives and exchange partners and the practice of small-scale enterprise. In their relationships with migrants, these social and economic meanings often converge. Alternatively, migrants with little or no incorporation in Lihir, or those from the third category, are typically glossed as ol autsait lain ('outsiders') or ol weira (effectively 'strangers'). The latter term is deliberately derogatory and may be applied to migrants from neighbouring islands or remote mainland districts as a way of positioning them in terms of perceived social connections or their 'rights' over mine-derived development.

Although in-migration has peaked throughout the mining era, during the colonial period large numbers of labourers were recruited from other parts of PNG to work on Lihir plantations (Bainton 2008: 297). Not all of these labourers were able to return to their home districts, and several of them are now quite elderly and find themselves especially dependent upon their landowner patrons and still work as labourers in order to survive (Figure 11.3). Rather than an instant influx, in-migration has increased in step with the development and expansion of the mining operation and the local economy. Migrants first arrived from the surrounding New Ireland and New Britain region, drawing upon established networks and relationships and settling in hamlets as incorporated guests in similar ways to some of the early informal settlements found in other urban areas in PNG (Numbasa and Koczberski 2012). While the number of migrants was comparatively low during this early period of mining operations, there was already a level of concern among some Lihirians about the prospect of further in-migration and the negative impacts that this might have. Women in particular were rather vocal about the prospect of migrant women seeking to marry Lihirian men in order to claim access to mine-related benefits.

10 Tok Pisin is the lingua franca in PNG and used in conversation between Lihirians and migrants. Lihirians generally communicate among themselves in the Lihirian language (but see Bainton 2015). 


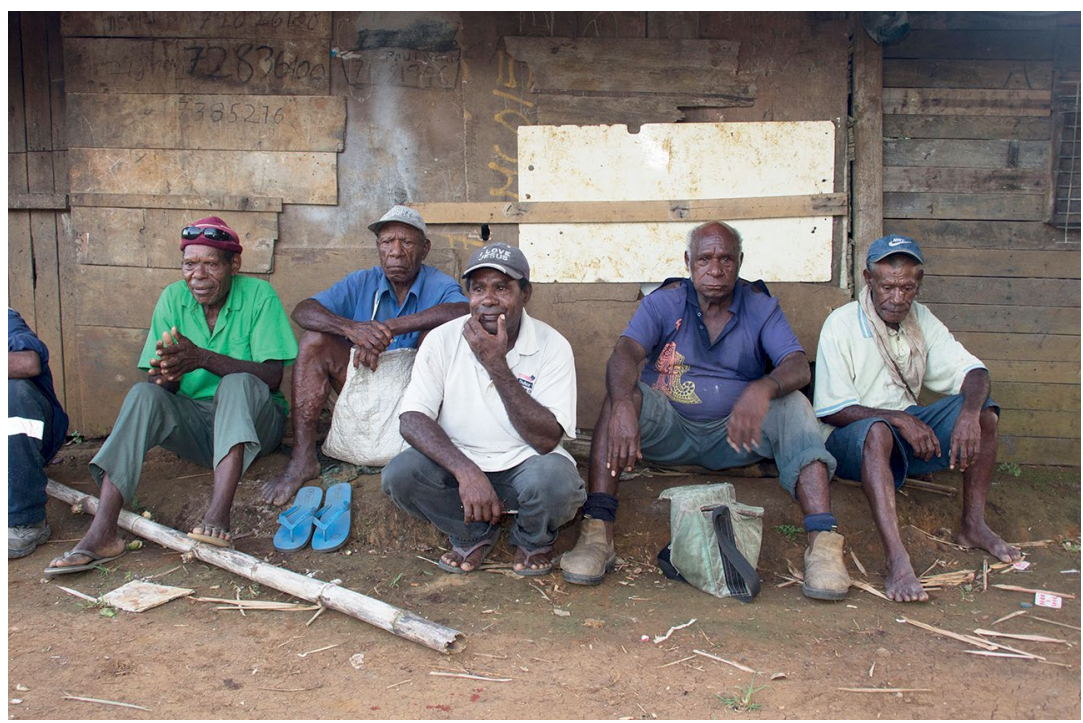

Figure 11.3 Former plantation labourers from Sandaun Province.

Note: Those shown are (from left to right) Thomas Waipano, Paulus Make, Nelson Sira, Camillus Mawe and Albert Esiuke.

Source: Photo by John Burton.

During this earlier phase there were fewer economic opportunities. The mining company was the main source of employment and nonLihirians were predominantly engaged on fly-in/fly-out rosters. Nevertheless, migrants still arrived in search of employment, moving between villages and attaching themselves to other migrants. In-migration was further encouraged by a small number of Lihirian men with prior business experience outside Lihir who later returned to establish small companies. Some of these men were shrewd businessmen, refused to employ relatives, and remained aloof in order to avoid demands from kin that would compromise their business pursuits (see Martin 2007). As local business development increased, more migrants were employed by private or local companies contracted to the mining operation, not all of which had formal provisions for accommodation. Many migrants came to sell goods at the town market, being regularly supplied by people from their home areas with betelnut and other produce for sale. These people were soon the target of Lihirian resentment as they were seen to be making money that Lihirians felt entitled to. In a typical chain migration sequence, these migrants were joined by other relatives seeking similar opportunities, although subsequent migrants were often far less incorporated, particularly unaccompanied young males. 
By the early 2000s, greater numbers of people were arriving from the Highland and Momase regions. One Lihirian man in particular provided initial support for migrants to settle in the previously unoccupied interior area between Londolovit and Kunaie villages, in the hamlets of Kul and Bombel. He was one of several outliers who bolstered personal support and renown through the patronage of migrant settlers. Before long, these interior hamlet areas were predominantly occupied by migrants. The growth of the migrant population is closely linked to the expansion of the local business environment, which has created a more diverse range of economic opportunities. Lihir is easily accessed by daily flights and the regular movement of dinghies from mainland New Ireland. The number of boats travelling to Lihir has increased as more money has spread throughout the region, and the advent of cheap mobile phones has enabled migrants to regularly contact relatives and friends to arrange their passage to Lihir or maintain a constant supply of market goods. Some of the more savvy entrepreneurs now utilise courier services to import goods and artefacts for sale. These strategies ultimately enable them to remain in Lihir for longer periods of time.

There is now a distinct clustering around the affected-area villages in the local government wards that are closest to the mine site (Figure 11.4) ${ }^{11}$ The number of people from New Ireland, and from the broader Islands, Momase and Highlands regions, has increased (Figure 11.5). Migrants outnumber Lihirians in Ward 1, and it is likely that they outnumber Lihirians in Ward 11 as well. The number of migrants residing in Putput village, in Ward 2, is comparatively lower, but the impact of their presence is compounded by existing land pressure and other rapid social changes related to resettlement. In these areas the migrant population is weighted towards younger mobile males from the Islands Region in the 20-35-year age range, but there are also many young families who seek employment and access to services and a small number of elderly migrants.

11 Due to the likely under-enumeration of the non-Lihirian population in the affected-area wards, an attempt has been made to reach a more conclusive estimate of the non-Lihirian population in these areas. Figure 11.4 presents positively enumerated figures. The adjusted population figures for nonLihirians are derived from certain assumptions based upon known residency patterns, the number of mapped residential structures, and average household numbers. See Vail (2011) for technical details for calculating the adjusted non-Lihirian figures. 


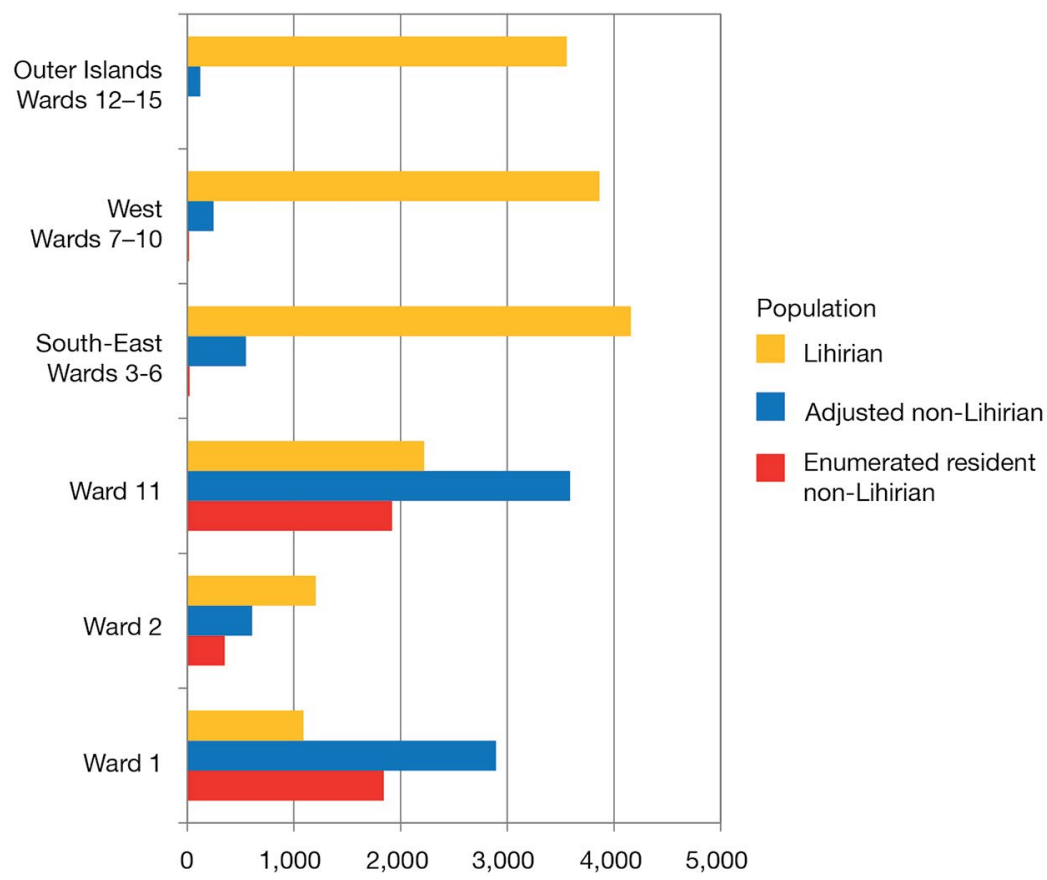

Figure 11.4 Enumerated Lihirian and non-Lihirian population figures, and adjusted non-Lihirian population figures, December 2013.

Source: Newcrest Lihir Social Impact Monitoring unit.

One of the most attractive services for migrant families is the wellresourced Lihir medical centre that provides vital primary health care to mine employees and the residents of Lihir. This has led to a form of 'medical tourism' as people come to access services that are not available elsewhere in the province, or many other parts of the country for that matter. ${ }^{12}$ While there have been major improvements in the health of the Lihirian community, successful health initiatives must also reach the migrant population, which is a considerably more difficult task. ${ }^{13}$

12 The Namatanai hospital, which is located in the nearest town on the mainland of New Ireland, also in the electorate of the former Minister for Mining, Byron Chan, has remained chronically dilapidated for many years. Redevelopment of the Namatanai hospital would certainly help to redirect in-migration and reduce the burden upon the Lihir medical centre, which has seen patient numbers more than double between 2005 and 2012, from approximately 36,000 to around 80,000 visits per year. In 2012, more than half of these patients were recorded as being contractors or their dependents, and the overall majority were recorded as non-Lihirians. More recently there has been a slight reduction in patient numbers due to the decline of contractor opportunities. However, there is still a need to integrate health service provisions across the district to meet future demands.

13 For more information on recent health programs see Bentley (2011) and Mitjà et al. (2011, 2012, 2013, 2015). 
Scheduled village health programs typically exclude the settlement areas, which is partly due to political decisions by Lihirian leaders to restrict the distribution of benefits. But, as health workers well understand, the settlement areas are only a short walk from the medical centre and the environmental conditions in these locations present major health risks for residents, which in turn places greater pressure upon health services.

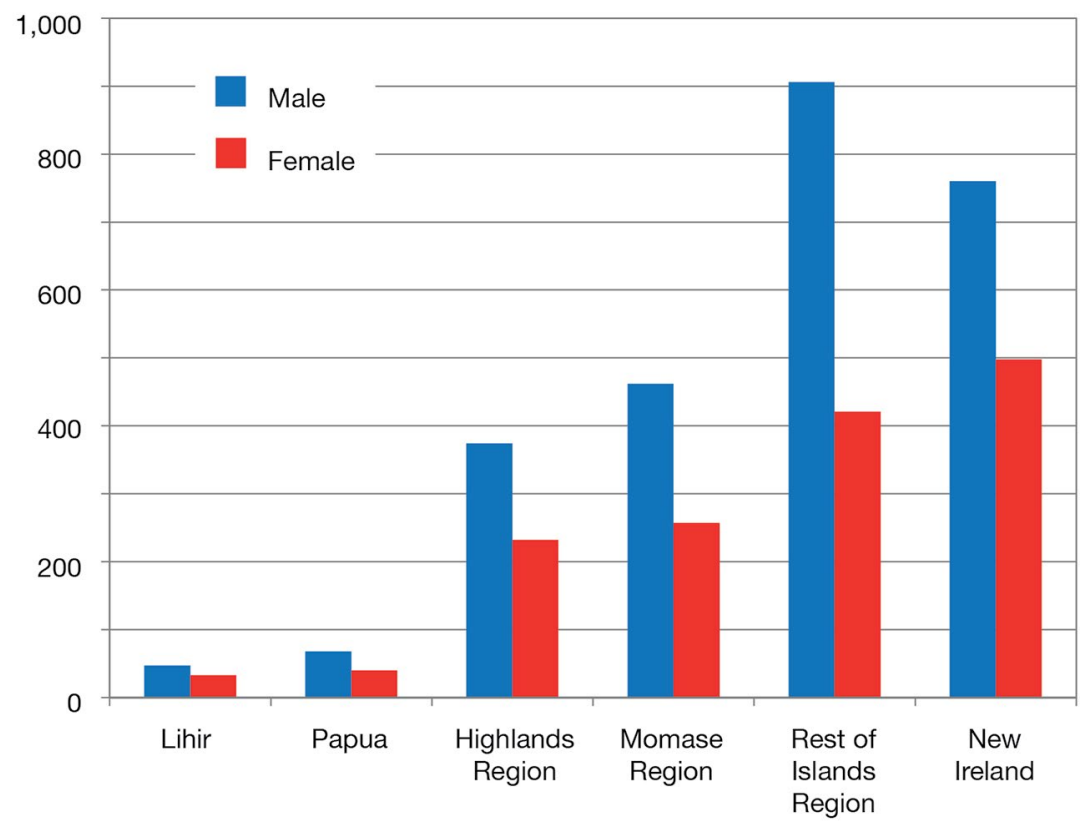

Figure 11.5 Birthplace of enumerated resident non-Lihirians, December 2013.

Source: Newcrest Lihir Social Impact Monitoring unit.

As the affected-area villages have been steadily urbanised, settlement patterns have remained regulated by customary land boundaries and more recent village planning exercises. On the other hand, in the interior hamlet areas of Kul and Bombel, and more recently the upper Londolovit and the Landolam valleys, settlement is more sporadic and opportunistic, and reflects more temporary arrangements. Although most of the migrants residing in these areas have limited social incorporation in Lihir, and have been the target of wider Lihirian frustration in relation to in-migration, many of these migrants remain in Lihir at the sufferance or direct sponsorship of specific landowners. However, as we shall see, many of these landowners have also lost control as patrons. 


\section{The Contractor Labour Force}

At its most recent peak in 2012, the mining company engaged a direct workforce of approximately 2,400 people and more than 4,100 contract labourers (NML 2013). In the earlier years of the operation, the contract labour force was considerably smaller, but as the project has expanded this has created more opportunities for local companies. Following the initial construction boom, the operation of the mine brought the need for reliable service provision and generated opportunities for local companies. These companies varied in size and composition and gained a range of business contracts including grass cutting, rubbish collection, gardening, transport services, construction, electrical and maintenance work and other mine-related services. From the outset, Lihirian landowners have been more interested in gaining business contracts for these services rather than performing the actual work themselves. This has opened up avenues for migrant labourers, many of whom have settled in the interior valleys and affected-area villages. By 2012, some 650 businesses were registered in Lihir, although certainly not all of these companies had contracts with the mine or any other kind of current operation. The largest and most successful of these business operations is the Lihirian-owned Anitua group of companies, which includes several companies that offer security, drilling, retail, catering and mining services. In 2012, the Anitua group employed over 2,000 people, with at least 45 per cent of its workforce coming from Lihir, 51 per cent from other parts of PNG, and the remainder from overseas.

Most of the companies in Lihir are small, locally owned businesses seeking contracts with the mining operation. Many of these companies provide labour hire services, sourcing Lihirian and non-Lihirian labourers for various work packages. Local businessmen not only recruit migrants on Lihir but regularly travel to other parts of PNG to find labourers for current or anticipated contracts. In 2008 the mining company commenced a major upgrade of the processing plant facilities, which included K40 million in seed capital to landowner companies, and provided millions of kina in commercial opportunities to local businesses. In order to maximise the contracting opportunities and to organise the distribution of the seed capital, Lihirian leaders amalgamated many of the smaller companies in a set of larger 'specific issues companies' that represent the landowners from particular lease areas (such as the plant site, the pit, the town and airport), collapsing the clan-based and geographical distinctions that 
operate elsewhere. This also had the peculiar effect of turning 'issues' into commercial entities, which has precluded the resolution of certain issues and guaranteed further 'compensation' through commercial contracts. Despite the anticipated economies of scale to be achieved through the consolidation of small and often unsustainable landowner companies, some landowners have found this umbrella model unsatisfactory. Not all of the new umbrella companies have operated effectively or regularly distributed dividends to the landowners they represent. Moreover, the distribution of contracting opportunities has remained uneven, which in turn has increased the existing divisions between landowners over access to business opportunities.

According to the environmental impact statement (EIS) for the plant upgrade, it was anticipated that the construction phase of this upgrade, completed in 2012, would require approximately 500 additional labourers (CNS 2009). Landowners and migrants took advantage of the opportunities for contract labour, and it now appears that a far greater number of hopeful migrant labourers have made their way to Lihir than what was originally projected in the EIS. ${ }^{14}$ The number of companies and labourers seeking contracts in Lihir has now outstripped the available opportunities. The proliferation of companies has arisen for several interconnected reasons: the perceived low start-up costs; the modern status associated with owning a business and employing people; a ready supply of migrant labour; and the expectation among landowners for business contracts based upon the belief that, because the mine is operating on their land within the lease areas, they are entitled to exclusive business opportunities, which is best characterised by the local catchcry 'my land, my work' (Bainton and Macintyre 2013). In this sense, landowner business development is perhaps better understood as another form of compensation or rent, or a kind of 'tax' levied against developers for access to resources. This kind of 'rentier capitalism' is now a common feature of the PNG resource sector and many landowners seem to conceptualise business development in terms of 'risk-free entrepreneurialism', which requires developers to carry the cost and exposure of local business development so that landowners might collect their due entitlement (Jackson 2015). If this appears to outside observers like a form of dependency or unsustainable development, from a local landowner

14 See Banks (2013) for a discussion on the social and environmental impact statement for the Lihir plant upgrade. 
perspective it is more likely perceived as a way of securing a guaranteed income for life, or at least exploiting an immediate opportunity. ${ }^{15}$ In the Lihir context, the relationship between landowners, migrants and the mining company is thoroughly shaped by local forms of patronage and the art of 'rentier leadership' (Burton 1997b).

\section{Housing the Labourers}

Two main scenarios for employee accommodation were tabled during the negotiation phase of the mine: a fly-in/fly-out arrangement and a fullscale mining town that would house workers and their families. Lihirian leaders wanted to maximise the opportunities for urban development and the associated economic spin-offs but feared the negative impacts that might accompany an influx of migrant workers. The end result was a combination of both options. The mining company utilised a dormant plantation on the Marahun plateau to construct a mining camp for flyin/fly-out employees. A purpose-built mining town was also developed adjacent to the camp with around 70 houses for expatriate and senior national employees who reside in Lihir with their families, and 35 houses for government employees. A local commercial service centre was constructed in the nearby lower Londolovit area (also previously used as a plantation), and a ring road was cleared around Aniolam Island linking all villages to the town and the camp. Prior to the establishment of Londolovit town, the nearby Potzlaka government station and the Palie mission station in the southwestern corner of the island were the only places that might be considered 'public' spaces, and were the main link to the outside world. The previous lack of transport options, compared with today, also ensured far less internal and outbound travel.

According to the terms of the 1995 mining development contract and the 2007 revised IBP agreement, non-Lihirian employees and contractors were to be engaged on fly-in/fly-out arrangements. Local Lihirian employees travel to work from their home villages, and it was originally hoped that this would generate less disruption to daily village life. The intention was to somehow 'contain' the large and predominantly male non-Lihirian workforce within the confines of the mining lease areas in order to limit

15 Thanks to Richard Jackson for bringing this point to my attention. 
the social footprint of the operation. This strategy is premised upon the developer being the main source of employment. However, as the number of landowner and joint venture companies operating in Lihir has increased, there has been a much higher demand for employee accommodation.

While some of the contracts gained by local companies include provisions for employee accommodation, this does not always ensure that these companies fulfil their obligations to their employees, including adequate accommodation, standard employee entitlements, or even regular meals. Some of the larger companies have built basic 'camp' accommodation, but in many cases non-Lihirian employees are forced to seek other arrangements. Not all of the Anitua group employees are housed within the mining camp, which is partly due to the size of the camp, but also because many of the lower-paid and semi-skilled positions do not include provisions for camp accommodation. For most migrants in Lihir, the primary intention is to gain employment or secure some form of livelihood. Access to land remains a secondary consideration since longterm residence is not the ultimate goal.

Since 1995, more than 1,000 permanent timber kit houses have been provided to the wider Lihirian community through the 'village development scheme' that is part of the IBP agreement (Figure 11.6). Lihirians have recognised a flourishing rental market, and many rent their new houses to migrant workers and their families. As more local businesses source migrant labour, there is a shortage of suitable accommodation. In the villages of Zuen, Kunaie, Londolovit and Putput, landowners can charge $\mathrm{K} 1,000-3,500$ (approximately $\mathrm{A} \$ 450-1,500$ ) per month to rent a wooden kit house. Most houses in these villages are connected to electricity and have access to rainwater tanks or mains water. The high rental rates do not always reflect real landowner expenses, especially given that most houses are provided under the benefits package. Landowners have seized upon the inflated resource economy and the demand for housing, and these rates could be seen as another type of 'tax' levied against migrants for access to Lihirian economic development. 


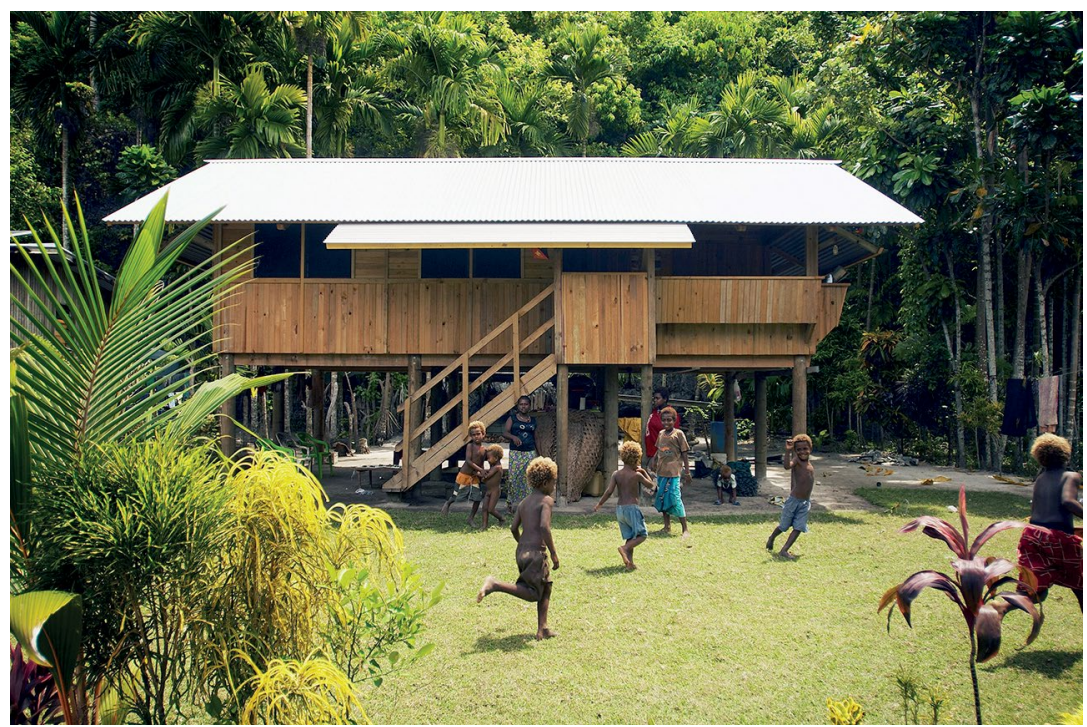

Figure 11.6 Village development scheme house.

Source: Photo by Nicholas A. Bainton.

For many migrant tenants, this is rarely an unproblematic rental arrangement. In some cases, landowners remain on the same block of land in a semi-permanent or bush material house and share water tanks and sometimes illegally connect electricity to their houses. These arrangements can create tensions between tenants and landlords, especially when tenants expect exclusive use of the house and any amenities. Some tenants complain that landlords demand additional contributions or advance payments on rent for customary feasting or other forms of daily consumption. ${ }^{16}$ This situation is only compounded by the absence of rental contracts.

16 For examples of these additional demands in other contexts, see Curry and Koczberski (2009), Allen (2012) and Koczberski et al. (2012). 


\section{Settlers, Squatters and Opportunistic Businessmen}

In Lihir the term 'rent' is applied loosely to cover a variety of informal arrangements that provide migrants with temporary access to housing or land upon which they may erect housing or grow food gardens. ${ }^{17}$ As yet, migrants have not utilised this land for agro-economic development, and there are few de facto changes to customary land tenure because Lihirians refuse to extend long-term use rights to migrant families. Effectively, landowners retain and exert their land rights: insecure or temporary use rights might be granted, and informal agreements established, but customary land is by no means alienated.

A technical legal distinction can be drawn between squatters, as people who enter and live on unoccupied land without permission, and settlers, who are invited to stay on land for a long period with express or tacit approval. In Lihir, these categories are often blurred and highly contextual. For instance, each of the 18 migrant settlement clusters identified in a social mapping exercise in the Landolam Valley area in 2011 were found to be sponsored by specific landowners (Burton and Onguglo 2011). Migrants living in these clusters exist in patron-client style relationships with individual landowners or local lineages. Some of these migrant settlers rent semi-permanent housing, while others are granted access to land upon which they erect makeshift homes. Settlers may pay from K20 to K100 on a semi-regular basis for access to land, and make additional contributions that help to sustain the relationship. Landowners often collect another form of 'rent' by asking a group of residents to 'raise funds' for an upcoming customary event. At the same time, many of these landowners also claim that they are overwhelmed by additional migrants who were not originally given permission to settle on their land regardless of any collective 'rental' payments that might have been made on their behalf. Rapid chain migration has meant that many landowners have lost control as patrons. Consequently, Lihirian political leaders often characterise all migrants as squatters, conveniently homogenising them as 'illegal trespassers'. In some cases the label is clearly correct, as people are squatting on customary or leased land without permission. In other cases,

17 This is similar to Koczberski et al.'s (2009: 35) observations in the PNG oil palm sector. See also Koczberski et al.'s (2017) discussion on informal land markets in PNG. 
migrants have ongoing economic and social relationships with individual landowners, complicating any simplistic image of migrants as unlawful tenants or parasitic vagrants.

In order to maintain use rights over land and access to residences, migrants frequently maximise new opportunities for social incorporation with Lihirian lineage groups. This is commonly expressed by migrants as: Mipela kamap bisnis wantaim sampela papagraon bilong Libir ('We are incorporated with some Lihirian landowners'); or Mipela pas wantaim dispela lain ('We are connected to this lineage group'). This relationship may be confirmed by Lihirians with expressions like: $\mathrm{Ol} i$ pas wantaim klen bilong $m i$ ('They are connected to my clan'); Ol $i$ kam ananit long lain bilong mi ('They are incorporated under our lineage'); or Em ol bisnis bilong mipela ('They are our "business"). In the context of landownermigrant relations, both the social and economic meanings of bisnis are emphasised. As migrant families become partially incorporated into Lihirian clans, as a sort of subgroup of the landowning lineage, the social (and economic) relationship is foregrounded and frames property rights. Migrants remain indebted to their hosts, who retain control over property and grant temporary forms of access. These relations are forged and maintained through contributions to funerals and large feasting and exchange activities (sometimes involving several thousand kina for the purchase of pigs), and more regular gifts of food and cash to landowner households and support for community projects. These public displays of support and involvement in community life confirm landowner patronage and help to erase the social differences that are made explicit in other contexts. At the same time, this can also compromise the ability of Lihirians to decide who resides upon their land or to remove unwanted tenants. Migrants have recognised the economic changes to customary activities and exploit the increased opportunities to establish and strengthen relationships with Lihirians. On the flip side, when rent or other contributions are not adequately distributed within the lineage, disgruntled members who fail to benefit from migrant settlers may well deny or contest their social inclusion, reflecting the vulnerable nature of migrant lives. 


\section{Vulnerable Migrants and Marginal Landowners}

At various times over the past ten years, the local political elite have incited community-level fervour for large-scale evictions, highlighting the contradictions in the relationship between Lihirians and migrants. This has generated a widespread desire for immediate action, and unfortunately reinforced the view among many people that the major social problems encountered in Lihir are best addressed through a singular focus on mass evictions. While much of this attention is directed at the growing number of people living in the interior areas close to the Londolovit town site, migrants residing in other villages are sometimes equally targeted. This is regardless of whether they are working for landowner companies and legitimately renting houses, or are young families eking out a living, or are some of the mass of mobile males 'drifting without kin', money or a connection to place (Reed 2003: 70).

This deliberate homogenisation reflects the larger sense in which Lihirians feel beset by migrant-related social changes. The close correlation between unmitigated in-migration, squatter settlements, growing law and order problems, and interethnic tensions between Lihirians and migrants, and between different migrant groups, has given rise to a definite sense of civic insecurity. This reached new heights in mid-2015 when several male migrants were arrested for torturing three women from Southern Highlands Province who were accused of sorcery by their fellow migrants and their Lihirian patron. Police station records show that in recent years there has been a definite increase in the number of reported crimes and charges. The data indicate that the migrant community has contributed to a quantitative shift in the level of social disturbance as the number of charges for theft, assault, sex-related crimes, drugs and general disturbances to public order have increased annually. Lihirian protestations would also suggest that the migrant community is solely to blame for a qualitative shift in social disturbance. However, such assertions are not supported by the records, which demonstrate that Lihirians are often involved or implicated in similar activities. On another level, even though Lihirian women may experience an acute fear of outsiders, especially in some affected-area villages where there is a high ratio of migrant males to females, these fears may be somewhat misplaced, since police and hospital records 
suggest that the level of domestic violence inflicted upon Lihirian women by their Lihirian husbands and relatives presents a more immediate threat to their everyday well-being.

The Lihirian tendency to attribute negative influences to the migrant population masks a certain level of social disintegration within Lihirian society. It also hides the ways in which the general vilification of migrants is intersected and undermined by individual interests and the social relations of compensation. This point is well illustrated in one documented instance involving a complicated dispute over a portion of land within the lease area in the Landolam Valley. This intergenerational and interclan dispute is the principal reason why one Lihirian family group has taken up residence on the lease, and have surrounded themselves with a considerable number of migrants who help them financially and offer moral support (Burton and Onguglo 2011). Their presence on the lease land was a double act of public defiance directed at the mining company and the landowner association, who they claimed had disregarded their land rights and denied them access to benefits and compensation. The senior widow of the lineage blamed her leg ailment on the landowner association-claiming she was poisoned by someone involved in the dispute-which resulted in her leg being amputated in 2010. She was then confined to a wheelchair that had to be carried across the boggy settlement grounds. A member of the association allegedly promised support for an artificial limb, but this never materialised, and in 2011 she died (Figure 11.7). Even if there is no discernible moral to this miserable outcome, this account demonstrates that not all landowner patrons are equally empowered, that some are even more vulnerable than their migrant tenants and are just as likely to be excluded by their fellow clan members on their own ground. And in this way the blanket characterisation of migrants helps to cover over some very uncomfortable social realities.

Eviction exercises planned by the local-level government have manifestly failed because of the tendency of landowners to consider 'their' migrants as useful guests (or economic resources), while all others are deemed an illegitimate nuisance. While a handful of landowners have evicted squatters from their land and burnt their houses, the historical lack of capacity within the local government to manage and mobilise coordinated eviction exercises, or deliver basic governance, has precluded meaningful action, reducing its efforts to vitriolic statements. Most Lihirians expect that the mining company will take direct action, which partly reflects the extent to which people feel overwhelmed and frustrated by current social 
changes, and the belief among some people that the company is both the source and only solution to these problems. At a minimum, there is a need for strong management of contract labour and the adequate provision of accommodation for contractor employees. In most cases, this is not the sort of action that Lihirians envision. This might even generate resistance from local businessmen who have come to rely upon ready access to a pool of migrant labour that can be easily mobilised for shortterm contracts. Rather, there is an expectation that the company will fund a private security firm to round up recalcitrant migrants and march them off the island. The contradiction between benefiting from migrant labour skills and simultaneously wanting to evict all outsiders is apparent.

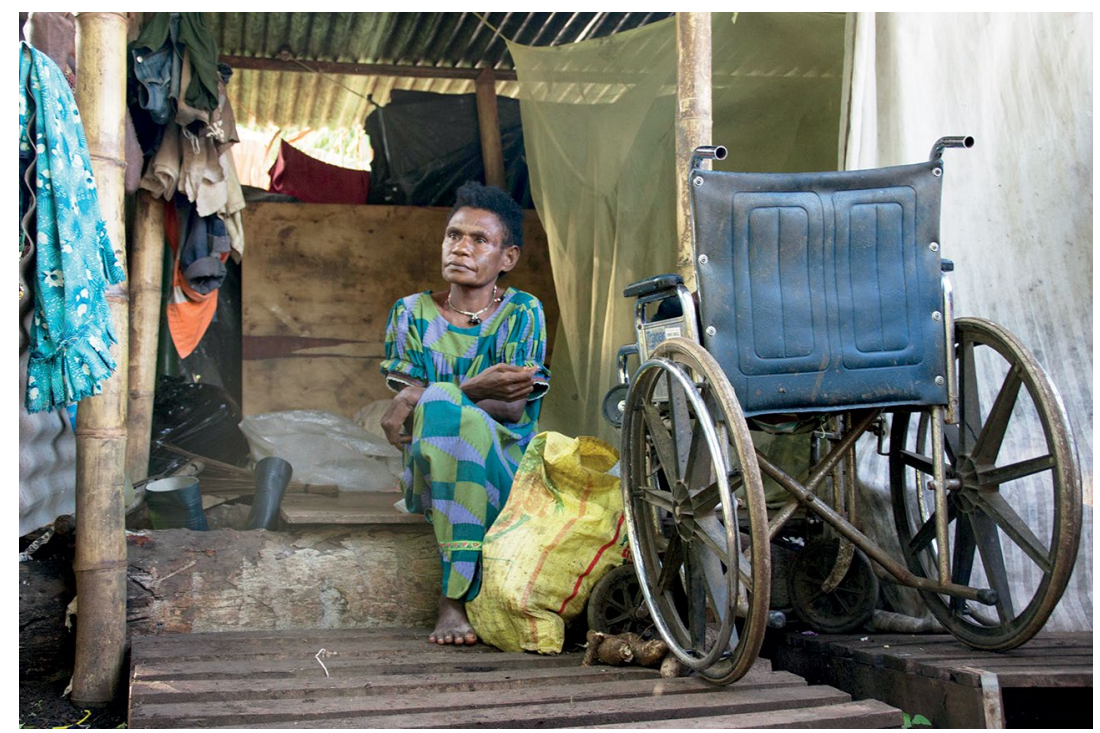

Figure 11.7 Late Anna Ikuluom of Tinetalgo clan in lower Landolam, 2011.

Source: Photo by Joyce Onguglo.

In these ways, Lihirian landowners, local business owners and the mining company provide a major pathway for in-migration. So, if it is true that some business owners have been hoodwinked into employing or entering into commercial arrangements with migrants, or have been overwhelmed by the effects of chain migration, then it is also the case that many have been blinded to these ramifications through their pursuit of business development, and that the mining company's contractor management processes have historically been inadequate for the task. The eagerness with which landowners have employed or entered into joint ventures 
with business-savvy migrants has only encouraged further in-migration and settlement. The inability or refusal of some landowners to accept responsibility for the welfare or actions of migrant employees and their families has directly contributed to the growing lack of control over the migrant population and the difficulties associated with retrospectively acknowledging and addressing these issues.

The other side of this scenario is the emergence of a vulnerable workforce. Classic labour theories tend to emphasise mobility as a key asset of the labourer. But in the PNG mining context it is questionable whether these theories are adequate. In Lihir, there are many migrant labourers and their families who experience entrenched conditions of unacceptable poverty and face considerable constraints upon their mobility. A lack of organised labour unions reduces their bargaining power and reinforces their reliance upon landowners for livelihoods and residence. The short-term nature of their employment contracts, the lack of suitable accommodation, the long working hours away from home, the inflated cost of living in a project enclave and their precarious social position place them under enormous pressure. These people live in a bind: they have less opportunity for investing in quality family life, better living conditions, or more sustainable livelihoods; there are few who can afford to travel back to their home village with their families; and they do not necessarily want to return to under-serviced rural areas. These migrants are perhaps better understood as a kind of 'landless rural peasantry', or a local example of the so-called 'precariat' (Standing 2011). Such vulnerability echoes Tawney's classic image of the 'man standing permanently up to the neck in water, so that even a ripple is sufficient to drown him' (Tawney 1932: 77). The total reliance upon landowners for land and livelihoods makes it difficult for migrants in this position to pursue alternative options. The deliberate conflation of migrant labourers and their families with more troublesome young mobile males ensures that the climate of fear is experienced both ways, ultimately exacerbating dependency upon landowner patrons.

\section{Conclusion: Some Practical Considerations}

The seemingly intractable challenges and impacts surrounding rural-toresource migration, and the difficulties that developers, landowners and governments encounter when addressing this issue, point to the need for greater attention to in-migration management strategies in the planning stages of resource projects. As detailed elsewhere (Bainton et al. 2017), 
the basic operational capabilities, or enablers, for understanding and managing in-migration are often missing in the industry's approach to social performance in practice. The planners and managers of many large-scale resource projects in PNG have paid insufficient attention to the different forms of in-migration that can occur throughout the life of a project, or the social and geographical factors that may influence these trends. The standards of planning and compliance that were common in the 1980s and 1990s - the period when several of the major projects currently operating in PNG were being developed-are no longer suitable (IFC 2012). International standards now require prospective projects to undertake detailed studies on potential project-induced in-migration and the related risks and impacts for the operation and host communities (IFC 2009). These standards also require the development of mitigation strategies to alleviate disturbances and risks associated with in-migration.

Freedom of movement is guaranteed in PNG's National Constitution, and developers cannot stop people migrating to project areas in search of new opportunities. This does not exempt developers from addressing in-migration, especially when in-migration becomes entwined with local contracting processes, or when migrants settle upon lease areas, or when they are severely disadvantaged. A lack of attention to the poor living and working conditions of subcontractors may result in these workers becoming 'hidden' within the overall workforce. These and other 'omitted social conditions' (Roberts 1995) of large-scale resource development represent another way in which the costs of production may be externalised on to local society. Ignoring in-migration until it results in operational, financial or reputational costs invariably creates situations where developers and local actors can only hope to address the symptoms of in-migration. The significant amounts of financial, legal and human resources that are directed towards reactive approaches to the impacts of in-migration detract from efforts to deliver upon agreed social and economic commitments to host communities. In the long run, this may well jeopardise a developer's ability to operate, as local frustrations mount over the slow delivery of benefits and agreed-upon projects, or the seemingly limited responses to migrant-related issues. Declining levels of community trust create further challenges for establishing more proactive approaches to in-migration that positively engage host communities and other relevant actors. 
Incursions on to lease land and the presence of illegal squatter settlements or relocated villages on lease areas create immediate operational risks. In 2010 the issue of project-induced in-migration at the Porgera gold mine became an international scandal when images of burning houses and homeless people appeared on the front pages of international newspapers, together with indignant statements on human rights by non-governmental organisations (Amnesty International 2010; HRW 2011). At the very least, increased scrutiny from the media and nongovernmental organisations requires developers to pay careful attention to the activities of employees, security personnel or police forces engaged in any form of migrant management, particularly where this may involve involuntary movement or resettlement. The tendency among some external commentators to look for simple moral narratives often obscures the complexity of these contexts, the factors that may influence company decisions, or the ways in which various state and local actors are also implicated. Recent access to smart phones and internet connectivity across PNG has also given rise to new forms of real-time exposure through the use of social media to broadcast or contest the real and perceived impacts of resource development. As a result, the planning and execution of any sort of relocation or broader 'population management' on or around lease land should be approached in a transparent rights-based manner.

Community members who feel overwhelmed by in-migration, regardless of their role in facilitating or hosting migrants, will often argue that developers are morally bound to provide assistance, since from their perspective it is the operation that has attracted in-migrants. In their efforts to avoid playing the role of a surrogate state, it is apparent that developers cannot unilaterally address the problems surrounding inmigration, which in turn points to more complex issues surrounding the limits or boundaries of corporate social responsibility (Banks 2006), and the difficulties involved in developing strong working partnerships with private companies, local communities and the public sector. Certainly the strategic investment in community development projects outside the core project area, in neighbouring towns or provincial centres for instance, could help to direct migrants away from affected areas. But the difficulties that many developers face in fulfilling their primary community obligations may well undermine these kinds of initiatives as lease-area landowners demand that all resources be invested locally. 
The Lihir context highlights the need for integrated approaches that extend beyond the immediate vicinity of lease areas and involve local, provincial and national actors. In PNG, these goals are hard to realise since developers often operate with limited input from state functionaries. This can be partly attributed to the isolation and remoteness of project locations, but is perhaps more closely related to the capacity and resourcing of state regulators. These conditions are further compounded by a lack of civil society in many mining locations. While provincial governments maintain strong interests in resource projects, their attention is usually directed towards the capture of royalties as opposed to managing sitespecific issues. These tasks are often left to landowners, developers and local-level governments. But as we have seen in Southern Highlands Province (Haley and May 2007), the amplified pressures of resource development may contribute to the collapse of local governance or the inability of local governments to provide the most basic public services, let alone address complex socioeconomic phenomena like in-migration.

In the end, developers and local authorities do well to remember that migrants provide much of the necessary entrepreneurial energy for the local economy, bring capital, innovation (both economic and cultural), specific skills and technical knowledge, and make up for labour shortfalls. From a provincial or national perspective, they are crucial in the wider distribution or remittance of benefits-financial, social, political and educational (Rigg 2007: 169). If this point is often lost in local discourses on in-migration, this reflects the complex connections between in-migration, livelihood strategies, identity, landownership and economic development. By drawing attention to these conjunctions, I have sought to illuminate some of the conditions of migrant lives in resource enclaves and the qualitative and quantitative features of rural-to-resource in-migration. Host communities of resource projects frequently face major social upheavals as large numbers of migrants come and reside on customary land yet exist outside traditional mechanisms for social control. These issues are often magnified on the PNG mainland, where project corridors and enclaves encompass larger and more diverse groups. But as the Lihir case demonstrates, small islands are by no means immune; the scale may be reduced, but in some ways the impacts can be more intense as they are compressed and contained within a smaller location. 


\section{Acknowledgments}

An early version of this chapter was presented at the Institute of Australian Geographers annual conference in 2009 and has benefited from helpful comments from John Connell and George Curry. A later version was also presented at the 2013 annual conference of the German Anthropology Association. Thanks to Bettina Beer and her colleagues for organising my involvement and for their feedback. Thanks to past and present staff and consultants of the Lihir gold mine social impact monitoring program, especially Elly Sawa, Walter Pondrelei, Ephraim Lenturut, Bill Sagir, Mary Arau, Bernadette Samsam, late Emma Zanahien, Jacinta Tami, Wesley Kenneth, Francis Kupe, John Vail, John Burton and Joyce Onguglo, and the team of Lihir village information officers. All have provided input into the demographic monitoring programs in Lihir over the years and their work has helped to inform this chapter. Thanks also to John Owen, Glenn Banks and Graeme Hancock for their comments on a draft version of this chapter.

\section{References}

Allen, M.G., 2012. 'Land, Identity and Conflict on Guadalcanal, Solomon Islands.' Australian Geographer 43: 163-180. doi.org/10.108 0/00049182.2012.682294

Amnesty International, 2010. Undermining Rights: Forced Evictions and Police Brutality around the Porgera Gold Mine, Papua New Guinea. London: Amnesty International.

Bainton, N.A., 2008. 'The Genesis and the Escalation of Desire and Antipathy in the Lihir Islands, Papua New Guinea.' Journal of Pacific History 43: 289-312. doi.org/10.1080/00223340802499609

_ 2009 . 'Keeping the Network out of View: Mining, Distinctions and Exclusion in Melanesia.' Oceania 79: 18-33. doi.org/10.1002/ j.1834-4461.2009.tb00048.x

—_, 2010. The Lihir Destiny: Cultural Responses to Mining in Melanesia. Canberra: ANU E Press (Asia-Pacific Environment Monograph 5). 
, 2015. 'The Lihir Language in Modern Historical Context.' In S. Ziegler (ed.), Karl Neuhaus's Grammar of the Lihir Language of New Ireland, Papua New Guinea. Boroko: Institute of Papua New Guinea Studies.

Bainton, N.A. and M. Macintyre, 2013. “"My Land, My Work”: Business Development and Large-Scale Mining in Papua New Guinea.' In F. McCormack and K. Barclay (eds), Engaging with Capitalism: Cases from Oceania. Bingley (UK): Emerald Group Publishing (Research in Economic Anthropology 33). doi.org/10.1108/s01901281(2013)0000033008

__ 2016. 'Mortuary Ritual and Mining Riches in Island Melanesia.' In D. Lipset and E.K. Silverman (eds), Mortuary Dialogues: Death Ritual and the Reproduction of Moral Community in Pacific Modernities. Oxford: Berghahn Books.

Bainton, N., V. Vivoda, D. Kemp, J. Owen and J. Keenan, 2017. 'ProjectInduced In-Migration and Large-Scale Mining: A Scoping Study.' St Lucia: University of Queensland, Centre for Social Responsibility in Mining.

Banks, G., 2005. 'Globalization, Poverty, and Hyperdevelopment in Papua New Guinea's Mining Sector.' Focaal 46: 128-143. doi.org/ $10.3167 / 092012906780786799$

__ 2006. 'Mining, Social Change and Corporate Social Responsibility: Drawing Lines in the Papua New Guinea Mud.' In S. Firth (ed.), Globalisation and Governance in the Pacific Islands. Canberra: ANU E Press.

— 2009. 'Activities of TNCs in Extractive Industries in Asia and the Pacific: Implications for Development.' Transnational Corporations 18: 43-60.

—_ 2013. 'Little by Little, Inch by Inch: Project Expansion Assessments in the Papua New Guinea Mining Industry.' Resources Policy 38: 688-695. doi.org/10.1016/j.resourpol.2013.03.003

Bentley, K., 2011. 2010 Lihir Social Demographic Health Survey. Canberra: Centre for Environmental Health Pty Ltd for Newcrest Mining Ltd. 
BGC (Barrick Gold Corporation), 2010. Porgera: 2010 Responsibility Report. Toronto: BGC.

— , 2012. 'Porgera Joint Venture.' Toronto: BGC.

Burton, J., 1994. 'The Lihir VPS Database: A Tool for Human Resources Planning, Social Development Planning and Social Monitoring.' Canberra: Pacific Social Mapping (Lihir Census Project Report 1).

_ 1997a. 'The Lihir VPS Database: Collection of Data for Monitoring.' Canberra: Pacific Social Mapping (Lihir Census Project Report 4).

—_, 1997b. 'C'est Qui, le Patron? Kinship and the Rentier Leader in the Upper Watut.' Canberra: The Australian National University, Resource Management in Asia-Pacific Program (Working Paper 1).

_ 2007. 'The Anthropology of Personal Identity: Intellectual Property Rights Issues in Papua New Guinea, West Papua and Australia.' Australian Journal of Anthropology 18: 40-55. doi.org/10.1111/j.18359310.2007.tb00076.x

Burton, J. and J. Onguglo, 2011. 'Social Impact Assessment of the LGL Lease Land Migrant Management Strategy.' Canberra: ANU Enterprise for Newcrest Mining Ltd.

Bury, J., 2007. 'Mining Migrants: Transnational Mining and Migration Patterns in the Peruvian Andes.' Professional Geographer 59: 378-389. doi.org/10.1111/j.1467-9272.2007.00620.x

Callister, G., 2008. 'Illegal Miner Study: Report on Findings.' Unpublished report by EMB Development Services Ltd and Rural Link Consultancies for Porgera Joint Venture.

Clunies Ross, A., 1984. Migrants from Fifty Villages. Boroko: Institute of Applied Social and Economic Research (Monograph 21).

CNS (Coffey Natural Systems Pty Ltd), 2009. Environmental Impact Statement: Million Ounce Plant Upgrade Project-Main Report, Volume 2). Melbourne: CNS for Newcrest Mining Ltd.

Connell, J., 2012. 'Population Resettlement in the Pacific: Lessons from a Hazardous History?' Australian Geographer 43: 127-142. doi.org/ $10.1080 / 00049182.2012 .682292$ 
Curry, G.N. and G. Koczberski, 2009. 'Finding Common Ground: Relational Concepts of Land Tenure and Economy in the Oil Palm Frontier of Papua New Guinea.' Geographical Journal 175: 98-111. doi.org/10.1111/j.1475-4959.2008.00319.x

Filer, C., 1992. 'The Lihir Hamlet Hausboi Survey: Interim Report.' Waigani: Unisearch PNG for Kennecott Explorations (Australia) and PNG Department of Mining and Petroleum.

—_, 1999. 'Introduction.' In C. Filer (ed), Dilemmas of Development: The Social and Economic Impact of the Porgera Gold Mine 1989-1994. Boroko: National Research Institute.

__ 2012. 'The Development Forum in Papua New Guinea: Evaluating Outcomes for Local Communities.' In M. Langton and J. Longbottom (eds), Community Futures, Legal Architecture: Foundations for Indigenous Peoples in the Global Mining Boom. Abingdon: Routledge.

Finer, M., C.N. Jenkins, S.L. Pimm, B. Keane and C. Ross, 2008. 'Oil and Gas Projects in the Western Amazon: Threats to Wilderness, Biodiversity, and Indigenous Peoples.' PLoS ONE 3: e2932. doi.org/ 10.1371/journal.pone.0002932

Goldman, L., 2009. 'Appendix 26: LNG PNG Social Impact Assessment 2008.' In Esso Highlands Limited, PNG LNG Project Environmental Impact Statement. Abbotsford (Victoria): Coffey Natural Systems Pty Ltd.

Golub, A., 2007. 'Ironies of Organization: Landowners, Land Registration, and Papua New Guinea's Mining and Petroleum Industry.' Human Organization 66: 38-48. doi.org/10.17730/ humo.66.1.157563342241q348

__, 2014. Leviathans at the Gold Mine: Creating Indigenous and Corporate Actors in Papua New Guinea. Durham (NC): Duke University Press.

Haley, N. and R.J. May (eds), 2007. Conflict and Resource Development in the Southern Highlands of Papua New Guinea. Canberra: ANU E Press (Studies in State and Society in the Pacific 3). 
HRW (Human Rights Watch), 2011. 'Gold's Costly Dividend: Human Rights Impacts of Papua New Guinea's Porgera Gold Mine.' Viewed 24 April 2017 at: www.hrw.org/en/reports/2011/02/01/gold-s-costlydividend

IFC (International Finance Corporation), 2009. Projects and People: A Handbook for Addressing Project-Induced In-Migration. Washington (DC): IFC.

— 2012. IFC Performance Standards on Environmental and Social Sustainability. Washington (DC): IFC.

Jackson, R., 2015. The Development and Current State of Landowner Businesses Associated with Resource Projects in Papua New Guinea. Port Moresby: PNG Chamber of Mines and Petroleum.

Kemp, D. and J.R. Owen, 2015. 'A Third Party Review of the Barrick/ Porgera Joint Venture Off-Lease Resettlement Pilot: Operating Context and Opinion on Suitability.' St Lucia: University of Queensland, Centre for Social Responsibility in Mining.

Kirsch, S., 2014. Mining Capitalism: The Relationship between Corporations and Their Critics. Oakland: University of California Press.

Koczberski, G., G. Curry and J. Anjen, 2012. 'Changing Land Tenure and Informal Land Markets in the Oil Palm Frontier Regions of Papua New Guinea: The Challenge for Land Reform.' Australian Geographer 42: 181-196. doi.org/10.1080/00049182.2012.682295

Koczberski, G., G. Curry and B. Imbun, 2009. 'Property Rights for Social Inclusion: Migrant Strategies for Securing Land and Livelihoods in Papua New Guinea.' Asia Pacific Viewpoint 50: 29-42. doi.org/ 10.1111/j.1467-8373.2009.01379.x

Koczberski, G., G. Numbasa, E. Germis and G.N. Curry, 2017. 'Informal Land Markets in Papua New Guinea.' In S. McDonnell, M.G. Allen and C. Filer (eds), Kastom, Property and Ideology: Land Transformations in Melanesia. Canberra: ANU Press. doi.org/10.22459/KPI.03.2017.05

Lavachery, P., S. MacEachern, T. Bouimon, B. Gouem Gouem, P. Kinyock, J. Mbairoh and O. Nkonkonda, 2005. 'Komé to Ebomé: Archaeological Research for the Chad Export Project, 1999-2003.' Journal of African Archaeology 3:175-193. 
Markey, S., 2010. 'Fly-In, Fly-Out Resource Development: A New Regionalist Perspective on the Next Rural Economy.' In G. Halseth, S. Markey and D. Bruce (eds), The Next Rural Economies: Constructing RuralPlace in GlobalEconomies. Wallingford (UK): CABI International.

Martin, K., 2007. 'Your Own Buai You Must Buy: The Ideology of Possessive Individualism in Papua New Guinea.' Anthropological Forum 17: 285-298. doi.org/10.1080/00664670701637743

McGavin, P.A., L.T. Jones and B.Y. Imbun, 2001. 'In Country Fly-In/ Fly-Out and National HR Development: Evidence from PNG.' In B.Y. Imbun and P.A. McGavin (eds), Mining in Papua New Guinea: Analysis and Policy Implications. Waigani: University of Papua New Guinea Press.

Meggitt, M. J., 1957. 'The Ipili of the Porgera Valley, Western Highlands District, Territory of New Guinea.' Oceania 28: 31-55. doi.org/ 10.1002/j.1834-4461.1957.tb00717.x

Mitjà, O., R. Hays, A. Ipai, M. Penias, R. Paru, D. Fagaho, E. de Lazzari and Q. Bassat, 2012. 'Single-Dose Azithromycin versus Benzathine Benzylpenicillin for Treatment of Yaws in Children in Papua New Guinea: An Open-Label, Non-Inferiority, Randomised Trial.' Lancet 379: 342-347. doi.org/10.1016/S0140-6736(11)61624-3

Mitjà, O., W. Houinei, M. Penias, A. Kapa, R. Paru, R. Hays, ... Q. Bassat, 2015. 'Mass Treatment with Single-Dose Azithromycin for Yaws.' New England Journal of Medicine 372: 703-710. doi.org/10.1056/ NEJMoa1408586

Mitjà, O., R. Paru, R. Hays, L. Griffin, N. Laban, M. Samson and Q. Bassat, 2011. 'The Impact of a Filariasis Control Program on Lihir Island, Papua New Guinea.' PLoS Neglected Tropical Diseases 5: e1286. doi.org/10.1371/journal.pntd.0001286

Mitjà, O., R. Paru, B. Selve, I. Betuela, P. Siba, E. de Lazzari and Q. Bassat, 2013. 'Malaria Epidemiology in Lihir Island, Papua New Guinea.' Malaria Journal 12: 98. doi.org/10.1186/1475-2875-12-98

Nash J. and E. Ogan, 1990. 'The Red and the Black: Bougainville Perceptions of Other Papua New Guineans.' Pacific Studies 13: 1-17. 
NML (Newcrest Mining Ltd), 2013. Newcrest Mining Limited Sustainability Report 2012. Melbourne: NML.

Numbasa, G. and G. Koczberski, 2012. 'Migration, Informal Urban Settlements and Non-Market Land Transactions: A Case Study of Wewak, East Sepik Province, Papua New Guinea.' Australian Geographer 43: 143-161. doi.org/10.1080/00049182.2012.682293

Owen, J. and D. Kemp, 2014. 'Mining-Induced Displacement and Resettlement: A Critical Appraisal.' Journal of Cleaner Production 87: 478-488. doi.org/10.1016/j.jclepro.2014.09.087

Reed, A., 2003. Papua New Guinea's Last Place: Experiences of Constraint in a Postcolonial Prison. New York: Berghahn Books.

Rigg, J., 2007. 'Moving Lives: Migration and Livelihoods in the Lao PDR.' Population, Space and Place 13: 163-178. doi.org/10.1002/ psp.438

Roberts, J.T., 1995. 'Subcontracting and the Omitted Social Dimensions of Large Development Projects: Household Survival at the Carajas Mines in the Brazilian Amazon.' Economic Development and Cultural Change 43: 735-758. doi.org/10.1086/452184

Robinson, R., 2014. 'Restoring Justice Initiative: Contributing to a Just, Safe and Secure Society in the Porgera District. Progress Report 2008-2014.' Unpublished report for the Restoring Justice Initiative.

Ryan, P., 1991. Black Bonanza: A Landslide of Gold. South Yarra (VA): Hyland Press.

Sidaway, J.D., 2007. 'Enclave Space: A New Metageography of Development?' Area 39: 331-339. doi.org/10.1111/j.1475-4762. 2007.00757.x

Smith, R.C., 2005. 'Can David and Goliath Have a Happy Marriage? The Machiguenga People and the Camasea Gas Project in the Peruvian Amazon.' In J.P. Brosius, A.L. Tsing and C. Zerner (eds), Communities and Conservation: Histories and Politics of Community-Based Natural Resource Management. Oxford: Alta-Mira Press.

Standing, G., 2011. The Precariat: The New Dangerous Class. London: Bloomsbury. 
Storey, K., 2001. 'Fly-In/Fly-Out and Fly-Over: Mining and Regional Development in Western Australia.' Australian Geographer 32: 133-148. doi.org/10.1080/00049180120066616

Strathern, M., 1975. No Money on Our Skins: Hagen Migrants in Port Moresby. Port Moresby: The Australian National University, New Guinea Research Unit (Bulletin 61).

Tawney, R.H., 1932. Land and Labour in China. London: Allen and Unwin.

Thibault, M. and S. Blaney, 2003. 'The Oil Industry as an Underlying Factor in the Bushmeat Crisis in Central Africa.' Conservation Biology 17: 1807-1813. doi.org/10.1111/j.1523-1739.2003.00159.x

Vail, J., 1995. 'All That Glitters: The Mt Kare Gold Rush and Its Aftermath.' In A. Biersack (ed.), Papuan Borderlands: Huli, Duna, and Ipili Perspectives on the Papua New Guinea Highlands. Ann Arbor: University of Michigan Press.

__, 2011. 'Lihir Demographic Summary 31/12/2010.' Unpublished report for Lihir Gold Limited. 
This text is taken from Large-scale Mines and Local-level Politics: Between New Caledonia and Papua New Guinea, edited by Colin Filer and Pierre-Yves Le Meur, published 2017 by ANU Press, The Australian National University, Canberra, Australia. 